\title{
Poems by Ingrid de Kok, Nuala Dowling, Loren Anthony and Johannes van Jerusalem; short fiction by John Eppel
}

Ingrid de Kok, Nuala Dowling , Loren Anthony , Johannes van Jerusalem \& John Eppel

To cite this article: Ingrid de Kok , Nuala Dowling , Loren Anthony , Johannes van Jerusalem \& John Eppel (2003) Poems by Ingrid de Kok, Nuala Dowling, Loren Anthony and Johannes van Jerusalem; short fiction by John Eppel, Scrutiny2, 8:1, 39-61, DOI: $10.1080 / 18125440308565995$

To link to this article: https://doi.org/10.1080/18125440308565995

曲 Published online: 31 May 2008.

Submit your article to this journal ๘

Џ Article views: 24

Q View related articles $\sqsubset$ 


\section{Spring custom}

INGRID DE KOK

As is the custom,

all winter long the wild canary

in its cage inside the cellar

is fed and cared for.

It sings its buoyant song

as if still skybound,

till its notes quaver

and it sings no more

in the damp dark;

not even when the farmer

opens the wooden shutters

for a dose of daily cellular light.

Months later, before dawn,

an early stamp of boots

brings the man to his silent bird.

He lifts the cage, cloth still on top,

and walks towards the woods.

Shafts of moving light

and soil smells strong as coffee

slowly filter through the bars,

till, hooked high in a spreading chestnut

the uncovered cage sways like a lantern

among the buds and shoots

and blue sky feathering trees.

The bird hiccups, tests its unpadlocked voice, and again, and then soars into song -

calling, we imagine, its lungs to free its wings. 
And calling, as was planned, the new-born

and migrating birds of spring

to closer and exposed view.

In the chestnut, pert and curious,

a bird party sings

without shadow or memory,

perhaps exhorting the canary

to find a mate, or explain its habitat;

while it sings back,

a duet we project our longings into,

despite our forebodings

because: there, we say,

are the trees, spring, and the wild birds

and there, the caged one about to be freed

and the farmer sharing the sun beside it.

But the farmer lifts his gun

and shoots as many as he can,

their bodies mostly too small to eat

though large enough

to spasm in the sky

before they fall

and are collected in a bag

on this bright morning

when now we hear

other guns shooting other birds

across the glittering Tuscan hills.

The caged canary,

shocked rigid

by the sudden shots,

smelling its betrayal

in gunpowder,

stops singing

until the following spring.

(From Terrestrial things Kwela/Snailpress, 2002) 


\section{The Archbishop chairs the first session}

\section{THE TRUTH AND RECONCILIATION COMMISSION. APRIL 1996. EAST LONDON, SOUTH AFRICA}

\section{INGRID DE KOK}

On the first day

after a few hours of testimony

the Archbishop wept.

He put his grey head

on the long table

of papers and protocols

and he wept.

The national

and international cameramen

filmed his weeping,

his misted glasses,

his sobbing shoulders,

the call for a recess.

It doesn't matter what you thought

of the Archbishop before or after,

of the settlement, the commission,

or what the anthropologists flying in

from less studied crimes and sorrows

said about the discourse,

or how many doctorates,

books and installations followed,

or even if you think this poem

simplifies, lionizes

romanticizes, mystifies.

There was a long table, starched purple vestment

and after a few hours of testimony,

the Archbishop, chair of the commission,

laid down his head, and wept.

That's how it began.

(From Terrestrial things Kwela/Snailpress, 2002) 


\section{Parts of speech}

\section{$\ldots \ldots \ldots \ldots$}

INGRID DE KOK

Some stories don't want to be told.

They walk away, carrying their suitcases

held together with grey string.

Look at their disappearing curved spines.

Hunchbacks. Harmed ones. Hold-alls.

Some stories refuse to be danced or mimed,

drop their scuffed canes

and clattering tap-shoes,

erase their traces in nursery rhymes

or ancient games like blindman's buff.

And at this stained place words

are scraped from resinous tongues,

wrung like washing, hung on the lines

of courtroom and confessional,

transposed into the dialect of record.

Why still believe stories can rise

with wings, on currents, as silver flares,

levitate unweighted by stones,

begin in pain and move towards grace,

aerating history with recovered breath?

Why still imagine whole words, whole worlds:

the flame splutter of consonants,

deep sea anemone vowels,

birth-cable syntax, rhymes that start in the heart,

and verbs, verbs that move mountains?

(From Terrestrial things Kwela/Snailpress, 2002) 


\section{The transcriber speaks}

INGRID DE KOK

I was the commission's own captive,

Its anonymous after-hours scribe,

Professional blank slate.

Word by word by word

From winding tape to hieroglyphic key,

From sign to sign, I listened and wrote.

Like bricks for a kiln or tiles for a roof

Or the sweeping of leaves into piles for burning:

I don't know which:

Word upon word upon word.

At first unpunctuated

Apart from quotations and full stops.

But how to transcribe silence from tape?

Is weeping a pause or a word?

What written sign for a strangled throat?

And a witness pointing? That I described,

When officials identified direction and name.

But what if she stared?

And if the silence seemed to stretch

Past the police guard, into the street,

Away to a door or a grave or a child,

Was it my job to conclude:

'The witness was silent. There was nothing left to say.'?

(From Terrestrial things Kwela/Snailpress, 2002) 


\section{The sound engineer}

Of the professionals engaged in Truth Commission

reporting, the highest turnover was apparently among

reporters editing sound for radio

\section{INGRID DE KOK}

From the speaker's mouth

through the engineer's ear,

sound waves of drought and flood

are edited for us to hear:

dunes filtering burnt desert sand,

corrupted wells, and shocks, shouts,

no longer muffled in the cochlea shell.

Listen, cut; comma, cut;

stammer, cut;

edit, pain; connect, pain; broadcast, pain;

listen, cut; comma, cut.

Bind grammar to horror,

blood heating the earphones,

beating the airwaves' wings.

For truth's sound bite

tape the teeth, mouth, jaw,

put hesitation in, take it out:

maybe the breath too.

Take away the lips.

Even the tongue.

Leave just sound's throat.

Keep your ear to the ground,

to pain's surfacing,

its gulp for air, its low ragged flight

over history's topography.

The instrumental ear

records the lesions of eroded land

while blood drums the vellum of the brain. 
A stain hovers like a small red butterfly

over the studio recording table

where the wall is listening,

so the ear dares to rest.

Then nothing.

Nothing but static,

insects invading air.

The sound engineer hears

his own tympanic membrane tear.

(From Terrestrial things Kwela/Snailpress, 2002) 


\section{Into the sun}

INGRID DE KOK

This is where landscape comes to die.

Where the forlorn wind

wails a little, sags a little,

brooding in the bluegum trees

just as it used to.

Where Sunday afternoons

threaten weekdays

with fitful narcotic sleep.

Where by day the hot sun is flat

and by night the cold moon is flat,

petrified in the stretched horizon

that the eyes inspect

on their level journey home.

Two verticals: industry's acropolis, the mine's meccano headgear, crow's nest over empty compounds; and abandoned mine dump middens, gold's necropolis.

As before the only colour other than ash and rock is the sunset pyre, its bloody ink dust motes beaten by disc ploughs, a Tretchikoff painting glaring you down.

And inside the stooped and stubborn silence a few men still walk miles along the main road to somewhere else much the same, straight into the sun without blinking. 


\title{
Compassionate leave
}

INGRID DE KOK

\author{
Almost everyone's on leave \\ gone away \\ to the countryside, \\ in threadbare trucks \\ to pay respects \\ in rooms and huts, \\ to watch and pray for dying ones \\ shrunken under sheets, \\ to vigils through the night \\ in closed-off streets \\ where grandmothers prepare \\ small and smaller funeral feasts \\ after truncated prayers \\ chanted by tired priests \\ over cardboard caskets \\ in the deathwatch heat. \\ Gone to taxi ranks and stations \\ to wait for information \\ from billboards, radios, \\ word of mouth and trumpets in the sky \\ where ubiquitous hadedas, \\ unlike Auden's mute impervious birds \\ blast their high shofars \\ over each infected space.
}

(From Terrestrial things Kwela/Snailpress, 2002) 


\section{Shops of my mother's imagination}

.. . . . . . . . . . . . . .

NUALA DOWLING

It is better to shop in the shops

of my mother's imagination.

They stock things like Optrex

and Yardley's Misty Beige foundation

(discontinued) and long-handled

dustpans and a remedy called Lexan

and very lightweight parasols and a cut

of meat she swears is called a Boston butt

and plain white cartridge for writing real letters

and finger-small bananas which she still remembers

from a long lost love affair in Barbados, West Indies. 


\section{Cecil Beaton is not dead enough}

NUALA DOWLING

Our daughters they are dieting to death:

it is time someone paid for the privilege.

"Who?" they asked me. I listed narrow minds

who conceived the fashion channel, wasted

writers of get-thin manuals, New York agencies

of brain diminishment and blood deficiencies,

editors and trimmers of all that nourishes, whoever

sells and draws fat profits from cellulite gels,

pop idols crammed into hungry, crying lyrics,

boys with funless stickers saying "No fat chicks"

and all photographers and shadowy image men,

all the way back to Cecil Beaton. "Cecil Beaton

is dead," said Sue. That may be, I said,

but Cecil Beaton is not dead enough:

he must die again. 


\section{It will be like this}

NUALA DOWLING

You will come down

in your dressing gown

and greet her, thinking

of your coffee, asking

"How are you?"

in a polite way

and she'll say,

"It's not good.

They shot him."

"Who?"

"My grandson."

And you will say,

"I am so, so sorry."

And there will be

a gesture. And you'll

give her money

towards the funeral, and say

"Take time off, have today."

But she'll smooth a faded

housecoat over her smart

city clothes and say,

"No, it's better to work,"

and look at the floor,

as if she might hurl

and clean it up herself. 
NUALA DOWLING

\author{
I have heard runts and gargoyles pontificate \\ and rate women on their busts and thighs \\ and outline precisely the shape which might \\ earn approval in their dull, impaired eyes; \\ and I have beheld brave women breasting \\ the waves graciously, figureheads of prize \\ ships, bringing gold coin for scurvy liars.
}


NUALA DOWLING

Though neither sheiks nor potentates

each straight man in Cape Town

has twenty wives: his own

his widowed mom

his wife's unmarried friends,

their single sisters

the spinsters and the divorcees

whose potential partners are

diving for doubloons off Cuba

trading bonds in Singapore

gathering meteorological data on Gough Island

attaching nodes to interfaces in Dublin

raising sheep in the Karoo

mining platinum in Rustenburg

running a kibbutz in Israel

or still here in Cape Town but

collecting porcelain and blow-drying hair.

So the straight man of Cape Town sighs

as he opens doors and walks behind

and pulls out chairs, listening with half an ear

to his wife's unmarried friends,

the spinsters and the divorcees

whose husbands left them

for a stripper or a teen 
for a change of woman

or for a change, a man,

whose ghost lovers left

for Cuba or for Dublin,

for Rustenburg or Singapore,

to farm in Carnarvon

or on a kibbutz

and so on,

ensovoorts. 


\section{Death of my Father. August 18th 2002}

LOREN ANTHONY

Old pharoah face

Waxen shape withered

To purple claws, bevelled contours

But something in your eyes I can never say what

Pins you to that bed

Waverley blanketed blue seal of yourself.

My creased father remnant with beautiful hair.

I shaved you one day careful not to nick.

Eyes closed, you breathed in metal blade and foam

Loving my hands

Working swiftly over stubble

Skin dragging behind the blade

Begging more.

A month later, my good brown dress is mourning torn

And you are folded away in your prayer shawl

Stained satin over faded black, beneath the pine lid.

Old men offer kid leather gloves and Karee leaves

In a freemason's send-off

And the Mourner's Prayer veins solemn, low.

I have not seen you dead.

Only the remembrance of

A ritual between father and daughter

Drags me towards the hole

and birds skid fast in the wind.

I had not thought it so difficult to put you to earth. 
LOREN ANTHONY

Chipped slave bells send

Sooty crows reeling into the air.

The pendulum taking its stupid route.

Then the magnificent hot press

Into

Red wax -

Wounding.

Out of scabbed black

Come blasts of a bugled tune

Old soldier notes from the last war.

Crows flying and flying and flying away

Finding bodies burst through

With earth.

On the sixth day treaties inked

Damply by clerical paws,

Some parts gilded like

Goldleaf.

No hardship there. 


\section{Winter}

LOREN ANTHONY

Webbed mornings

Ligaments of frost and

Cold dew

Dark evergreens stiffening.

It rained late this year.

On the crossbars of the washing line

Buffed pearls cling -

A necklace of weak light.

Frayed flannel whispers as she

Tries to coax heat

From glass-blue legs.

It is too dark in the house

The thin green smell of damp,

Soured incontinence.

Even now, a hot track veins her legs.

Mixed Fruit Jam and Bread and Trinco Tea

Fill her mouth. Jam on her shirt front.

Boxes of old letters

Preoccupy her - wasted stamps,

Looped cursive, nothing of

Consequence.

A pleating reflex makes her tug at the blanket fabric,

Smelling of mothballs.

She drifts off, warmed by the past.

Trees blacken; day is over. 


\section{Telkom laying pipes in the suburbs}

....................

LOREN ANTHONY

Night the colour of liquorice

Charring brown to black.

Thick heat blurs the

Borders.

A brazier sweating late,

The chained rottweiler leaps to the green mesh

A shadow lynching itself perfectly.

The men are laying pipes.

For four months

They have lived behind the green mesh,

Corrugated plates sheilding

Them from curious suburban eyes.

In the morning

Before the bulbuls,

The lorries lead out of the

Compound in an orderly manner.

PVC pipes form pyramids

In blue

In white.

The children who've come to play tennis

Play instead between the pipes

Faces in the cones

Hidden from sight.

We do not know how long they

Will be here.

Theirs is a settlement

More solid than ours. 


\title{
Love in this age
}

JOHANNES VAN JERUSALEM

\author{
I do not \\ want to come \\ inside you \\ I just \\ want to kiss you \\ and touch \\ your secret parts.
}

This is called Love

in the Age of Disease.

We erect barricades

around our fleshiness

and feign

a new innocence

and breed guilt

and regret

over our hidden

unprotected encounters

with each other

and look at each other

shamefully

and sadly

in the daylight.

We keep

our distances. 
Only this

remains to save ourselves:

Let's smash down

the walls

and make love

naked,

to the bone.

Let's bare even

the veins,

let blood

touch blood

and liver liver,

let the guts intermingle

until no one

can distinguish this Soul

from that Soul

and this Heart

from that Heart.

Let us scare away

all fear

of death

in this way,

and in this way

at last

enter

the great Age

of Ease. 


\section{The victim}

\section{JOHNEPPEL}

\section{The Officer in charge}

After a tip-off by the public at large we proceded to the bush there by Circular Drive. We found the body hanging from a tree. He was using a leather belt. Yes, he was naked, and it is true what you say, but those who laughed, they were seriously reprimanded.

We unhooked the belt, put the body in a plastic, and took it to the Mpilo mortuary for identification. Yes, too full. You wouldn't believe. We had to leave it there on the ground. Then we were looking for someone to identify the body. Ja. Terrible.

\section{Constable M}

We could not help it to laugh. His penis was erect. Like this.

\section{Constable N}

No, we didn't remove the belt. Because that is not our job. All we did is our job.

\section{The victim's brother}

When the police came and told me, I was very sad. My sister, she cried, but I did not cry. Only when I saw my brother - the oldest boy - lying there with no clothes and with his belt, which was my father's, who is now late ... his belt ...

Yes, my mother is also late. Now it is just me and my young sister. My uncle sends us money from South Africa. I change it with Vapastori ... is why my brother went to jail. The police catch him changing forex with Vapastori. Fort Street.

I had to undo the belt. It was too tight. I could not look at him. I cried all the time. Yes, they did. They found his clothes in the bush and gave them to me.

\section{The victim's sister}

When they released him he looked terrible. His skin was like ash. He wouldn't look at us or even talk to us. Mostly he lay on his bed. He cried quietly, sometimes, all night. No, he wouldn't eat a thing. Not even chicken. He just lay there.

His girlfriend did not even know he was out of jail. His friends. Nobody.

Yes, he was in a lot of pain. I think his bottom was very sore. He wouldn't let us help him. He turned away from us. He used to be such a happy boy always laughing and joking. Lots of girls.

\section{The prison officer}

Yes, it is officially forbidden to lock up children with adults, but we do it all the time. They pay us well and it makes them less aggressive. Sometimes it is very hard to control these people.

I do remember him, but it was not I who smuggled him from the juvenile block to the adult block. That was another officer. No, I can't do that. No, I don't feel bad. Why should I feel bad? He was exchanging 
money on the parallel market. He was unpatriotic. We are a sovereign country. We are tired ...

\section{The rapist}

I paid a lot of money for that "woman". All my forex. But I got it back in a few weeks by renting him out to other prisoners. No, he was easy to hide in these overcrowded cells. And he was very small.

That is not true. He screamed a lot because of the sores, but how can you say he didn't like it when I can bring you witnesses to prove that he sometimes got an erection. Strewsgod. Like this.

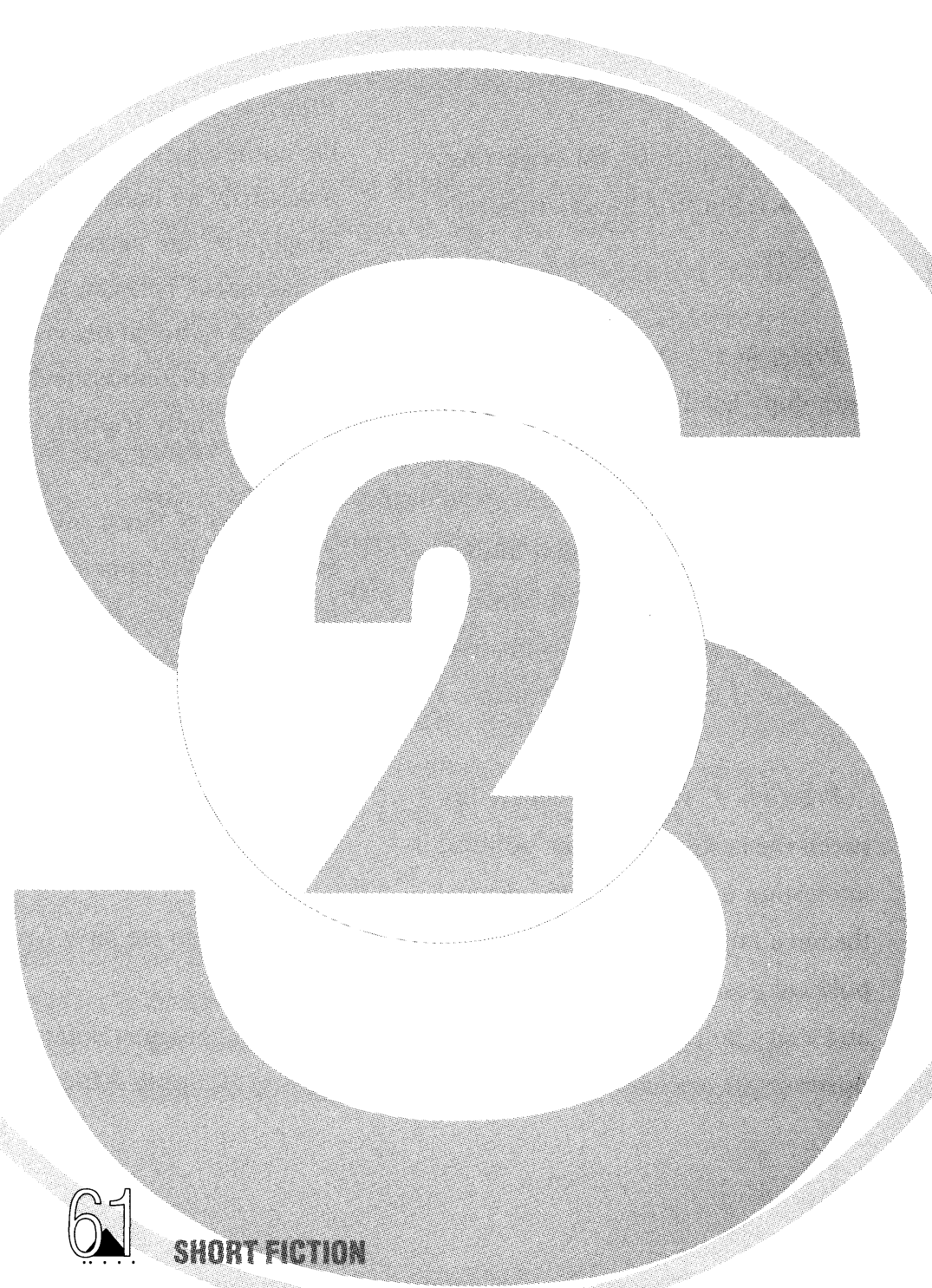

